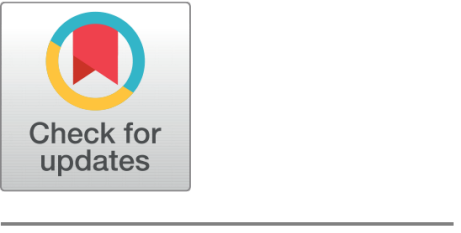

OPEN ACCESS

Received: 14-07-2020

Accepted: 04-08-2020

Published: 19-08-2020

Editor: Dr. Natarajan Gajendran

Citation: Sathya TN, Mehta VA, Devi Senthil , Navaneethakrishnan KR, Murugan SS, Kumaravel TS (2020) Cytotoxicity evaluation of CELNORM, a nutritional health supplement, on MCF7 breast cancer cells . Indian Journal of Science and Technology 13(30): 3070-3075. https ://doi.org/10.17485/IJST/v13i30.1150

*Corresponding author.

kumaravelts@gIrlabs.com

Funding: None

Competing Interests: None

Copyright: $(2020$ Sathya et al. This is an open access article distributed under the terms of the Creative Commons Attribution License, which permits unrestricted use, distribution, and reproduction in any medium, provided the original author and source are credited.

Published By Indian Society for Education and Environment (iSee)

ISSN

Print: 0974-6846

Electronic: 0974-5645

\section{Cytotoxicity evaluation of CELNORM, a nutritional health supplement, on MCF7 breast cancer cells}

\author{
T N Sathya ${ }^{1}$, Vijay A Mehta ${ }^{2}$, Devi Senthil ${ }^{3}$, K R Navaneethakrishnan ${ }^{4}$, \\ S S Murugan ${ }^{5}$, T S Kumaravel ${ }^{6 *}$ \\ 1 Regulatory Toxicologist, GLR Laboratories Private Limited, \#444, Gokulam street, Mathur, \\ Chennai. PIN - 600068 \\ 2 Founder and Chairman, Retort Pharmaceuticals Private Limited, \#21/2, McNichols Road, \\ Chetpet, Chennai, PIN -600031 \\ 3 Group Product Manager, Retort Pharmaceuticals Private Limited, \#21/2, McNichols Road, \\ Chetpet, Chennai, PIN -600031 \\ 4 Assistant Director, GLR Laboratories Private Limited, \#444, Gokulam street, Mathur, \\ Chennai. PIN - 600068 \\ 5 Managing Director, Dept. of Toxicology, GLR Laboratories Private Limited, \#444, Gokulam \\ street, Mathur, Chennai. PIN - 600068 \\ 6 Chairman, GLR Laboratories Pvt Ltd, and Head of Toxicology and Risk Assessment., GLR \\ Laboratories Private Limited, \#444, Gokulam street, Mathur, Chennai. PIN - 600068
}

\section{Abstract}

Objective: To evaluate the in vitro cytotoxic potential of CELNORM, a nutritional health supplement, on MCF7 human adenocarcinoma breast cancer cells. Methods: Briefly, MCF7 cells were cultured for 24 hours in complete growth medium containing fetal bovine serum and antibiotics and exposed to various concentrations $(500,250,125,62.5,31.25,15.625,7.8125,3.906$ micrograms $/ \mathrm{mL}$ ) of CELNORM for a period of 24 hours. Cell viability/death was assessed qualitatively by microscopy and quantitatively by MTT assay. Findings: CELNORM exhibited significant cytotoxic effect on MCF-7 cells in a dose dependent manner. Under microscopy, there was an evident, dosedependent increase in the number of apoptotic cells. Cell viability exhibited in terms of percentage viability, fell below $70 \%$ from $7.9 \mu \mathrm{g} / \mathrm{mL}$, which is indicative of cytotoxic response from this dose. The $\mathrm{IC}_{50}$ value was determined to be $43.51 \mu \mathrm{g} / \mathrm{mL}$. Applications: With such an effective combination of natural ingredients, the results are promising. Therefore, we conclude that CELNORM can be a useful option in the supplemental therapy for breast cancer treatment in the panel of Complementary and Alternative Medicine (CAM).

Keywords: CELNORM; breast cancer; cytotoxicity; MCF7; complementary and alternative medicine

\section{Introduction}

Breast cancer has been reported as the most common type of malignancy among women worldwide. Despite the advancements in therapy, it still remains the most leading and common cause of death in women suffering from the disease ${ }^{(1,2)}$. A recent review 
by Azamjah et al. ${ }^{(3)}$ indicated a significant increase in breast cancer mortality rate in the world during the past 25 years, which could be due to increase in incidence and prevalence of this cancer. Several attempts are being made to improve the survival rate of the afflicted women population.

It is a well-known fact that the treatment of cancers involves the use of chemotherapeutic drugs and /or radiation depending on a variety of factors. These treatment options are evidently not harmless and there is a certain amount of risk that is involved, in the form of side effects. On the contrary, the use of natural supplements and practicing a healthy lifestyle can be a useful option as a prophylactic and curative measure for the treatment of cancer. In the last few years, the use of Complementary and Alternative Medicine (CAM) has been on the rise in the cancer survivors, who undergo cancer treatment with conventional therapies including chemotherapy and radiotherapy ${ }^{(4)}$. Natural products which include dietary supplements and phytotherapeutic products are one of the CAMs that are utilized by these patients ${ }^{(5,6)}$.

With this background, we investigated CELNORM, a nutritional supplement manufactured by Retort Laboratories Pvt. Ltd for its ability to kill breast cancer cells, using in vitro methods, as an initial screening. CELNORM is a completely natural health supplement made of extracts of carrot, cucumber, an active component curcumin and a bio enhancer. Since breast cancer is one of the most common cancers worldwide, we initiated testing with these cells. We used MCF-7, which is a human breast cancer cell line with characteristics of differentiated mammary epithelium, such as the processing of estrogen through the estrogen receptors in the cell cytoplasm.

\section{Materials and Methods}

CELNORM was manufactured (Date of Manufacture: July 2019, Date of Expiry: July 2021) and supplied by Retort Pharmaceuticals Pvt. Ltd (Manufacturing Plant: No.1, Milk colony road, Madhavaram, Chennai- 600060) for testing. It is constituted of root extracts of carrot, fruit extracts of cucumber, an active ingredient curcumin (Purity: 95\%) from the rhizome of turmeric and a bio enhancer. All the constituents were confirmed to be devoid of microbial contamination and heavy metal content within acceptable limits through the supplier's Certificate of Analysis.

MCF-7 breast cancer cell line, was procured from the National Centre for Cell Sciences (NCCS), Pune. India. The identification of the cell line was assured through the cell line authentication report provided by the supplier (molecular analysis). The cells were passaged in Dulbecco's Minimal Essential Medium (DMEM) supplemented with 10\% Feta Bovine Serum (FBS) and antibiotics (Penicillin-streptomycin) and maintained under aseptic conditions as applicable for in vitro cell culture. All media and reagents were cell culture grade.

\subsection{Preparation of the test sample}

About $30 \mathrm{mg}$ of CELNORM was initially dissolved in $95 \mu \mathrm{L}$ of Dimethyl Sulfoxide (DMSO) and made up to $3 \mathrm{~mL}$ with serum free medium. From this stock, serial dilutions were made to obtain the various concentrations for testing $(3.9,7.8,15.125,31.25$, $62.5,125,250$ and $500 \mu \mathrm{g} / \mathrm{mL})$.

\subsection{Cell seeding and treatment}

MCF-7 breast cancer cells were seeded @ $1 \times 10^{4}$ cells/well in a microtiter plate. After a $24 \mathrm{~h}$ incubation, the cells were treated with $100 \mu \mathrm{L}$ of the various concentrations of the test sample. Solvent control wells received the same concentration of DMSO used for preparation of the test sample. Appropriate number of blank wells were maintained. Six wells were used for each treatment. Following treatment for $24 \mathrm{~h}$, cell viability was assessed by MTT assay.

\subsection{MTT assay}

After incubation, the cells were examined under an inverted microscope for morphological evidence of cytotoxicity. Immediately after the microscopic assessment, $50 \mu \mathrm{L}$ of MTT solution was added to each well. The plate was then incubated at $37^{\circ} \mathrm{C}$ for $3 \mathrm{~h}$ in a $5 \% \mathrm{CO}_{2}$ atmosphere. Following incubation, the MTT solution was removed and $100 \mu \mathrm{L}$ of isopropanol was added to each well to dissolve the formazan crystals. The plate was shaken and the resulting formazan solution was analyzed using a microplate reader (Mindray MR-96A) at $546 \mathrm{~nm}$ using the blank as reference. MTT absorbance was expressed in terms of absolute optical density OD546 (OD546; which was OD546 of the treated culture -mean OD546 of blanks). The IC 50 value was determined using the AAT Bioquest Software. 


\section{Results and Discussion}

At 24 hours, the 96-well plate was observed under an inverted microscope for evidence of cytotoxicity. From the representative photomicrographs shown in Figure 1, there is an evident dose- dependent increase in the number of rounded cells indicative of apoptosis. At the highest dose tested $(500 \mathrm{ug} / \mathrm{mL})$, more than $90 \%$ of the cells were apoptotic or towards apoptosis.

Figure 1: Photomicrographs representing cytotoxicity in MCF7 cells upon treatment with CELNORM.

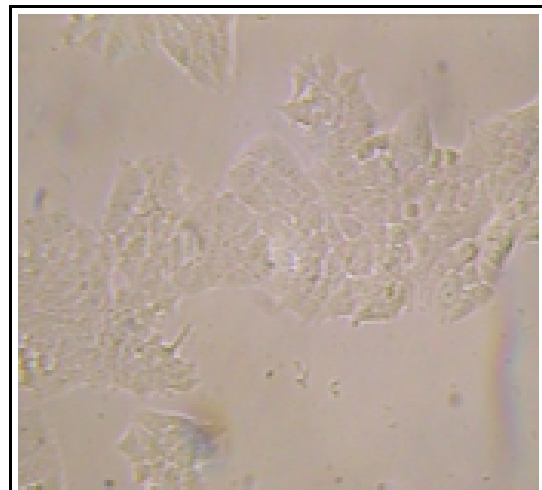

Fig 1a: Solvent Control

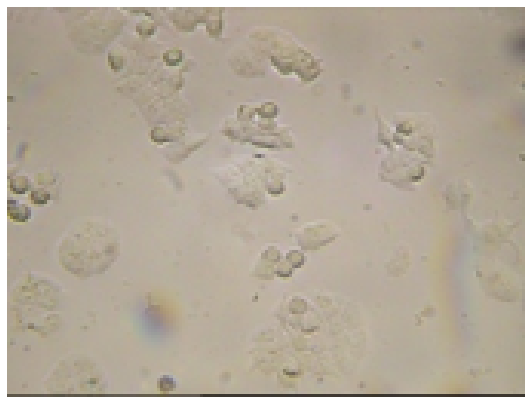

Fig 1d: CELNORM $15.125 \mu \mathrm{g} / \mathrm{mL}$

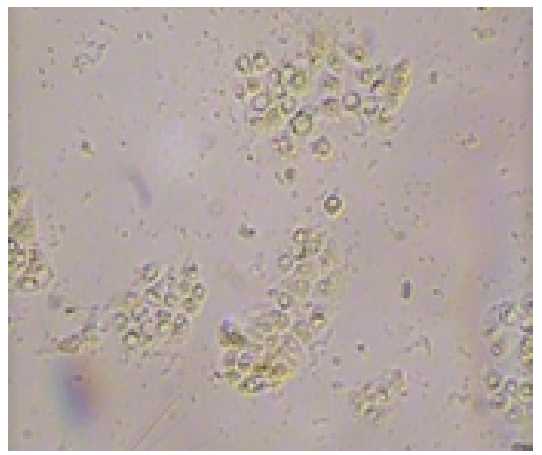

Fig 1g: CELNORM $125 \mu \mathrm{g} / \mathrm{mL}$

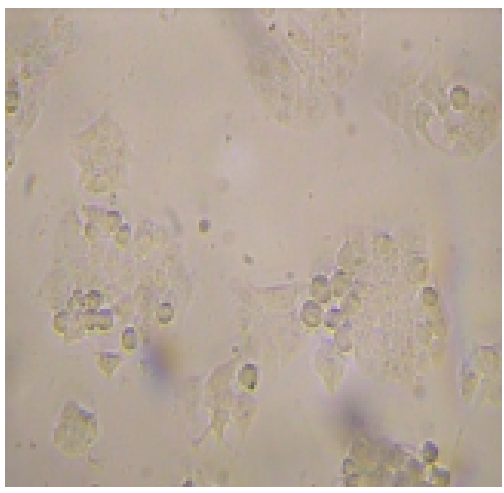

Fig 1b: CELNORM $3.9 \mu \mathrm{g} / \mathrm{mL}$

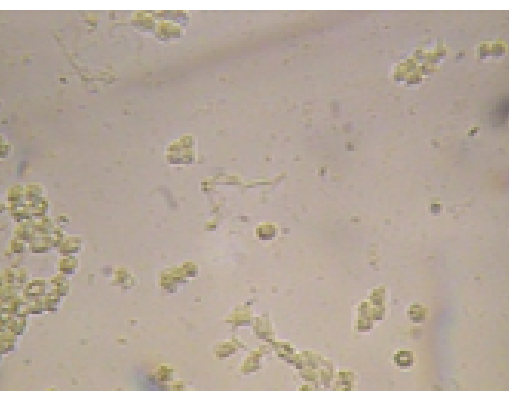

Fig 1e: CELNORM $31.25 \mu \mathrm{g} / \mathrm{mL}$

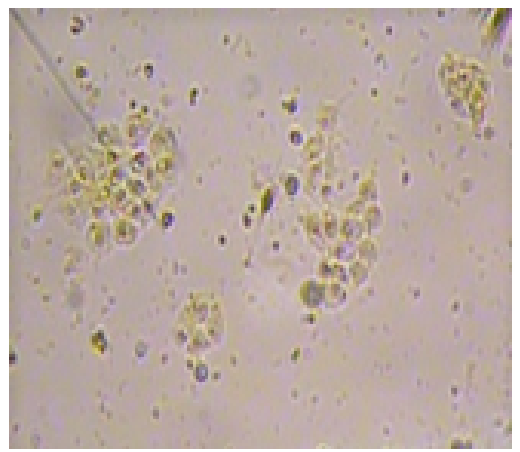

Fig 1h: CELNORM $250 \mu \mathrm{g} / \mathrm{mL}$

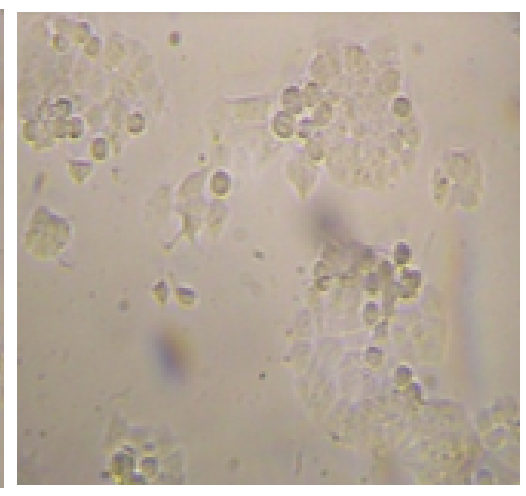

Fig 1C: CELNORM $7.8 \mu \mathrm{g} / \mathrm{mL}$

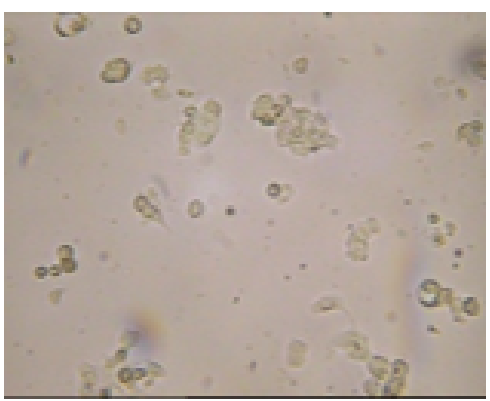

Fig 1f: CELNORM $62.5 \mu \mathrm{g} / \mathrm{mL}$

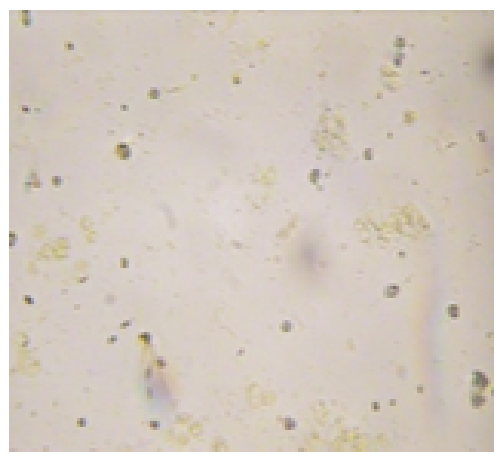

Fig 1i: CELNORM $500 \mu g / m L$

Fig 1. 
In cytotoxicity assays, cell viability below $70 \%$ upon treatment is considered as a cytotoxic effect. Following the MTT assay, cell viability in treated cells fell below $70 \%$ from $7.9 \mu \mathrm{g} / \mathrm{mL}$ and the extent of cytotoxicity increased with increase in dose ( Figure 2). The $\mathrm{IC}_{50}$ was calculated using the AAT Bioquest software and determined to be $43.51 \mu \mathrm{g} / \mathrm{mL}$.

There is a continuous search for novel molecules and combination of existing molecules for their application in the treatment of breast cancer. Recently, Hassan et al. reported that gold (III) complex and its ligand exhibit strong cell-growth inhibition against MCF7 with MTT assay implying complex-induced apoptosis in breast cancer cells. A non-steroidal inhibitor, anastrazole has also shown promising cytotoxicity in MCF7 cells in a dose dependent manner with an elevation in cell membrane permeability, cytochrome $c$, and nuclear intensity. Changes in mitochondrial membrane potential and a decreasing cell viability level were also reported. Heterocyclic compounds such as 1,3,4-thiadiazole derivatives have been shown to cause cytotoxicity in breast and prostate cancer cells in vitro. Eupatorine, a methoxy flavone flavonoid was reported to induce apoptosis and concurrently inhibit the invasion, migration and angiogenesis of MDA-MB-231 and MCF-7 cells through inhibition of Phospho-Akt pathway and cell cycle blockade ${ }^{(7-10)}$.

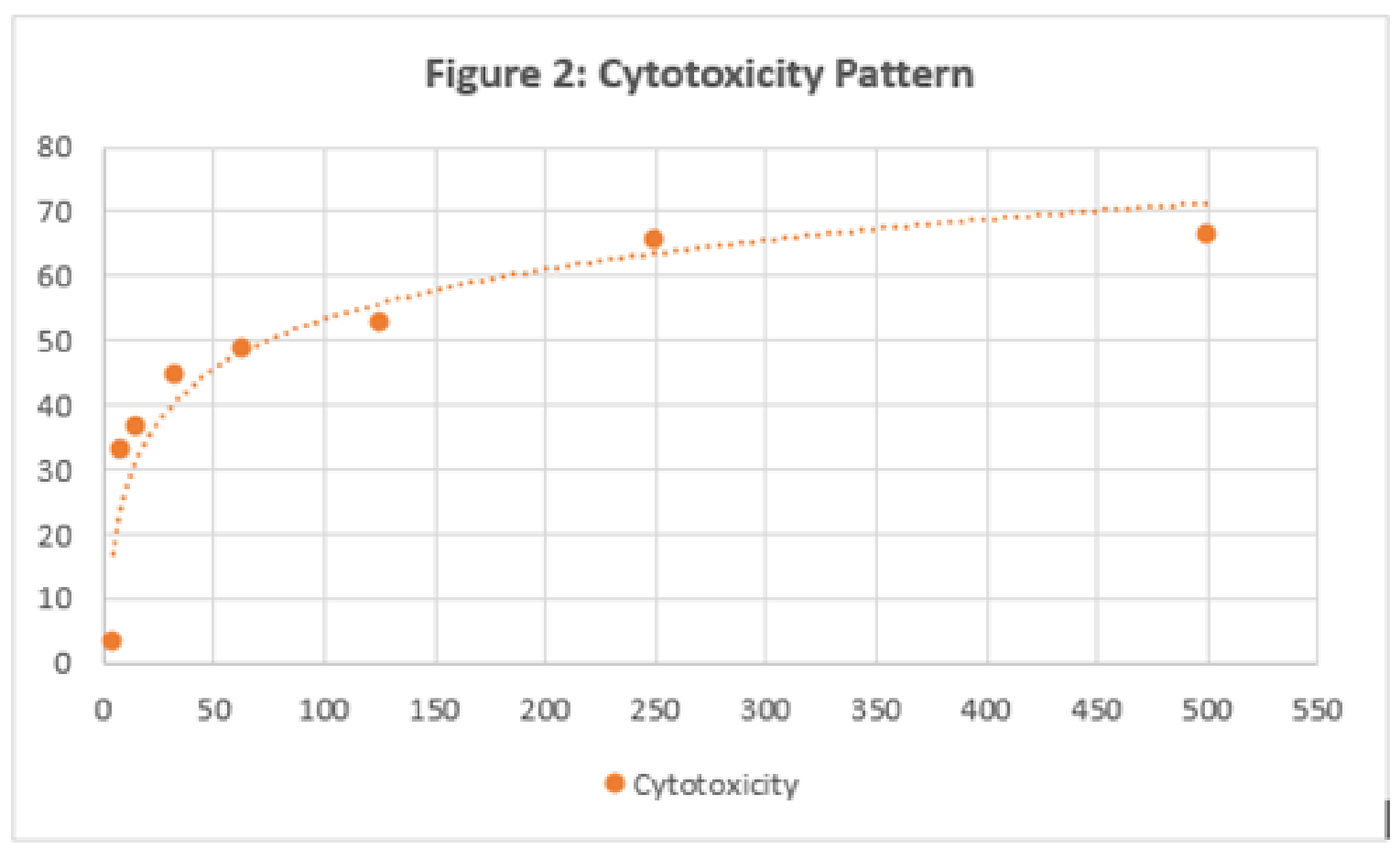

Fig 2.

It is a well-known fact that the treatment of cancers involves the use of chemotherapeutic drugs and /or radiation depending on a variety of factors. These treatment options are evidently not harmless and there is a certain amount of risk in the form of side effects. The use of natural supplements and practicing a healthy lifestyle may be considered as a useful option as a prophylactic and curative measure for the treatment of cancer.

With this background, the present study was designed to evaluate CELNORM for its cytotoxic potential in human Caucasian adenocarcinoma (breast cancer) cell line MCF-7. Since breast cancer is one of the most commonly occurring cancers worldwide, these cells were chosen for testing.

CELNORM, a natural health supplement with carrot, cucumber and an active ingredient from turmeric was anticipated to have cytotoxic effect on cancer cells owing to its very composition. Each ingredient has its own share contributing to the cytotoxic effect on the breast cancer cells. There is an appreciable synergistic response on the breast cancer cells. Microscopic 
examinations of the treated cells indicate that with increase in the dose, more cells are entering into apoptosis. These effects were seen just in $24 \mathrm{~h}$ of treatment and with increase in time, the cytotoxic potential would be much higher. Since nutritional supplements are prescribed for a long time, the benefits of these phytochemicals in combating cancer is expected to be exponential.

According to the U.S. National Cancer Institute (NCI) and Geran ${ }^{(11)}$, an $\mathrm{IC}_{50}$ range between 21 and $200 \mu \mathrm{g} / \mathrm{ml}$ is considered as moderately cytotoxic for crude plant extracts. The $\mathrm{IC}_{50}$ obtained for CELNORM being $43.51 \mu \mathrm{g} / \mathrm{ml}$, can be considered moderately cytotoxic and close to the highly cytotoxic range $(<20 \mu \mathrm{g} / \mathrm{ml})$.

It is a fact that phytochemicals can modulate carcinogenic signaling pathways through several crucial mechanisms of action including the effects on Cell cycle, apoptosis, angiogenesis and cell adhesion, Epigenome, Cancer stem cells, Antioxidant and genoprotective effects. Understanding the mechanisms of phytochemicals can be informative in strategizing new chemopreventive diet in the fight against cancer ${ }^{(12)}$. The mechanisms of action involved in the major active components - curcumin in turmeric, the luteolins in carrot and cucurbitacin in cucumber are well-established.

Curcumin has anti-proliferative and apoptotic activities by various pathways in MCF-7 cells ${ }^{(12-14)}$. It has the ability to cell lines to anticancer drugs ${ }^{(15)}$. In addition, curcumin has been demonstrated to cause cytotoxic activity on cancer stem cells. The inhibition of cancer stem cells suppresses metastasis and reattachment, ultimately limiting tumor formation, which makes it an ideal candidate for drug development ${ }^{(16)}$.

A recent meta-analysis indicated that high carrot intake was associated with decreased risk of breast cancer. Although this evidence was gathered based on case-control studies, it certainly has important public health implications ${ }^{(17)}$. The presence of luteolin in carrot may be considered as the major factor contributing to this effect. Luteolin (2-[3,4-dihydroxyphenyl]-5,7dihydroxy-4-chromenone), is a flavonoid found in fruits and vegetables, including carrot, that exhibits anticancer properties ${ }^{(18)}$. In MCF7 breast cancer cells, luteolin has been shown to induce apoptosis through both extrinsic and intrinsic pathways. Luteolin causes increase in DR expression and the subsequent activation of the caspases 8 and 3 leads to apoptosis of the cells by the extrinsic pathway; on the other hand, luteolin increases Bax expression and lowers expression of Bcl-2 ${ }^{(19)}$. In addition, luteolininduced apoptosis in prostate and breast cancer cells has also been associated with inhibition of fatty acid synthase (FAS), a key lipogenic enzyme that is upregulated in many human cancers ${ }^{(20)}$. Interestingly, luteolin has been shown to suppress metastatic breast cancer, which is a remarkable property of this flavonoid ${ }^{(21)}$.

Cucurbitacins, found in cucumber, have been identified to have remarkable anticancer properties. Different cucurbitacin compounds reportedly exhibit antiproliferative and cytotoxic properties on various cancer cell lines, including breast cancer. The most predominant mechanism for the apoptosis-inducing effect of cucurbitacins are their ability to modify mitochondrial trans-membrane potential and regulate the expression of genes related with apoptosis. Cucurbitacins are known to selectively inhibit the JAK/STAT pathways ${ }^{(22)}$.

\section{Conclusion}

We report in this study, the cytotoxic potential of a nutritional supplement, CELNORM, containing a combination of natural extracts. It contains an effective combination of phytochemicals that can elicit a powerful cytotoxic response on breast cancer cells, including the breast cancer stem cells. In addition, the major advantage of using nutritional supplements of natural origin, as a supplemental therapy for cancer is that no side effects are anticipated. With such an effective combination of natural ingredients with proven anticancer potential, the results are promising. Therefore, we conclude that CELNORM can be a reliable and useful for inclusion in the supplemental therapy for breast cancer treatment in the panel of Complementary and Alternative Medicine (CAM). However, the modality of administration of CELNORM, as supplementary therapy including dosage and curative duration without imposing possible side effects among needed human population will be the futuristic study of interest.

\section{References}

1) Rossi RE, Pericleous M, Mandair D, Whyand T, Caplin ME. The role of dietary factors in prevention and progression of breast cancer. Anticancer Research. 2014;34(12):6861-6875.

2) Sorlie T, Perou CM, Tibshirani R, Aas T, Geisler S, Johnsen H, et al. Gene expression patterns of breast carcinomas distinguish tumor subclasses with clinical implications. Proceedings of the National Academy of Sciences. 2001;98(19):10869-10874. Available from: https://dx.doi.org/10.1073/pnas.191367098.

3) Azamjah N, Soltan-Zadeh Y, Zayeri F. Global Trend of Breast Cancer Mortality Rate: A 25-Year Study. Asian Pacific Journal of Cancer Prevention. 2019;20(7):2015-2020. Available from: https://dx.doi.org/10.31557/apjcp.2019.20.7.2015.

4) Lopes CM, Dourado A, Oliveira R. Phytotherapy and Nutritional Supplements on Breast Cancer. BioMed Research International. 2017;2017:1-42. Available from: https://dx.doi.org/10.1155/2017/7207983.

5) Complementary, Alternative, or Integrative Health: What's in a Name?. 2015. Available from: https://nccih.nih.gov/health/integrativehealth.

6) Nagykálnai T, Landherr L, Nagy AC. Vitamin D and breast cancer. Orvosi Hetilap. 2014;155(28):1091-1096. Available from: https://dx.doi.org/10.1556/ oh.2014.29906. 
7) Hassan F, Mohammed SAAQ, Philip A, Hameed AA, Yousif E. Gold (III) Complexes as Breast Cancer Drug. Systematic Reviews in Pharmacy. 2017;8(1):7679. Available from: https://dx.doi.org/10.5530/srp.2017.1.13.

8) Hassan F, El-Hiti G, Abd-Allateef M, Yousif E. Cytotoxicity anticancer activities of anastrozole against breast, liver hepatocellular, and prostate cancer cells. Saudi Medical Journal. 2017;38(4):359-365. Available from: https://dx.doi.org/10.15537/smj.2017.4.17061.

9) Hassan F, Hairunisa N, Mohammed SA, Yousif E. A Study on Antitumor Effect of 1,3,4-Thiadiazole Derivatives in Prostate and Breast Cancer Cell Lines (In Vitro). 2017.

10) Razak NA, Abu N, Ho WY, Zamberi NR, Tan SW, Alitheen NB, et al. Cytotoxicity of eupatorin in MCF-7 and MDA-MB-231 human breast cancer cells via cell cycle arrest, anti-angiogenesis and induction of apoptosis. Scientific Reports. 2019;9(1). Available from: https://dx.doi.org/10.1038/s41598-01837796-w.

11) Geran RI, Greenberg NH, Macdonald MM, Shumacher AM, Abbott BJ. Protocols for screening chemical agents and natural products against animal tumors and other biological systems. Cancer Chemotherapy Reports, Part III. 1972;3:1-103.

12) Kubatka P, Liskova A, Kello M, Mojzis J, Solar P, Solarova Z, et al. Plant-derived functional foods with chemopreventive and therapeutic potential against breast cancer: A review of the preclinical and clinical data. In: Kabir Y, et al., editors. Functional Foods in Cancer Prevention and Therapy. Academic Press. 2020;p. 283-314.

13) Hu S, Xu Y, Meng L, Huang L, Sun H. Curcumin inhibits proliferation and promotes apoptosis of breast cancer cells. Experimental and Therapeutic Medicine. 2018;16(2):1266-1272. Available from: https://doi.org/10.3892/etm.2018.6345.

14) Liu J, Pan Y, Chen O, Luan Y, Xue X, Zhao J, et al. Curcumin inhibits MCF-7 cells by modulating the NF- $\kappa$ B signaling pathway. Oncology Letters. 2017;14(5):5581-5584.

15) Liu H, Ho Y. Anticancer effect of curcumin on breast cancer and stem cells. Food science and human wellness. 2018;7:134-137. Available from: https://doi.org/10.3892/ol.2017.6860.

16) Kakarala M, Brenner DE, Korkaya H, Cheng C, Tazi K, Ginestier C, et al. Targeting breast stem cells with the cancer preventive compounds curcumin and piperine. Breast Cancer Research and Treatment. 2010;122(3):777-785. Available from: https://dx.doi.org/10.1007/s10549-009-0612-x.

17) Chen H, Shao F, Zhang F, Miao Q. Association between dietary carrot intake and breast cancer A meta-analysis. Medicine (Baltimore). 2018;97(37). Available from: https://doi.org/10.1097/MD.0000000000012164.

18) Lin Y, Shi R, Wang X, Shen H. Luteolin, a flavonoid with potentials for cancer prevention and Therapy. Current Cancer Drug Targets. 2008;8(7):634-646. Available from: https://doi.org/10.2174/156800908786241050.

19) Park S, Ham S, Kwon TH, Kim MS, Lee DH, Kang J, et al. Luteolin Induces Cell Cycle Arrest and Apoptosis Through Extrinsic and Intrinsic Signaling Pathways in MCF-7 Breast Cancer Cells. Journal of Environmental Pathology Toxicology and Oncology. 2014;33(3):219-231. Available from: https://doi.org/10.1615/JEnvironPatholToxicolOncol.2014010923.

20) Brusselmans K, Vrolix R, Verhoeven G, Swinnen JV. Induction of Cancer Cell Apoptosis by Flavonoids Is Associated with Their Ability to Inhibit Fatty Acid Synthase Activity. Journal of Biological Chemistry. 2005;280(7):5636-5645. Available from: https://dx.doi.org/10.1074/jbc.m408177200.

21) Cook MT. Mechanism of Metastasis Suppression by Luteolin in Breast Cancer. Breast Cancer. 2012;10:89-100. Available from: https://doi.org/10.2147/ BCTT.S144202.

22) Alghasham AA. Cucurbitacins : A Promising Target for Cancer Therapy. International Journal of Health Sciences. 2013;7(1):77-89. Available from: https://dx.doi.org/10.12816/0006025. 